\title{
Breathy shame and the place of Hebrew in the work of Jerome of Stridon
}

This article analyses the place of Hebrew in Jerome's work by situating it in wider patterns of late antique masculinity and shame. Drawing on Kosofsky Sedgwick and Fanon, it shows how shame is a spatial affect. Discussions of Hebrew in Jerome's work emphasise the particular spaces in which Hebrew is written, read, or transported. One space is particularly important for Jerome's Hebrew translation: the space of the mouth as it inhales and exhales language. Focussing on space, language, and breath reveals why Hebrew is particularly shameful for Jerome and explains some of the apparent ambiguities in his discussions of translation.

Keywords: Jerome; masculinity; Hebrew; breath; shame.

\section{1: INTRODUCTION}

In the early 380s, Damasus, bishop of Rome, received a letter from Jerome. ${ }^{1}$ In this letter Jerome argued that competence in Hebrew was essential for correct biblical reading. ${ }^{2}$ In the beginning, says the letter, all human beings spoke Hebrew and this was the language of creation, the language that Adam and Eve spoke, and the original tongue in which things were named. Through this common language human beings were able to organise themselves so that they could build the tower at Babel. This tower caused offence (offensa) to God who then scattered human beings across the earth and rent the fabric of human language. ${ }^{3}$ For Jerome, then, language is both the means by which humans communicate and the source of their alienation from each other. So begins the story of human diversity.

This brief reference to human origins comes in a wider discussion in which Jerome claims that Hebrew can help the Christian exegete understand the divine economy of time and space and thereby to discern the actions of the Word in history. By example, he offers an interpretation of the vision of the Lord and the seraphim in Isaiah. ${ }^{4}$ The letter insists that the

\footnotetext{
${ }^{1}$ Jerome, Epist. 18A (CSEL 54.73-96)

2 Andrew Cain, The Letters of Jerome: Asceticism, Biblical Exegesis and the Construction of Christian Authority in Late Antiquity (Oxford: Oxford University Press, 2009), 53.

${ }^{3}$ Jerome, Epist. 18A.6 (CSEL 54.82.5): Postquam uero in fabricatione turris per offensam dei linguarum diuersitas adtributa est, tunc sermonis uarietas in omnes dispersa est nationes.

${ }^{4}$ Jerome, Epist. 18A.6 (CSEL54.81.4)
} 
two seraphim in the vision have been misinterpreted by other commentators. Seraph in Hebrew, writes Jerome, means either 'fire' (incendium) or 'the beginning of his speech' (principium oris eorum) ${ }^{5} \mathrm{He}$ then argues that 'fire' refers to Christ, while 'the beginning of his speech' can only refer to the language of the Old Testament. Hebrew was, after all, the primary language and the construction of Babel was accomplished thanks to this common tongue. ${ }^{6}$ Looking more carefully at the Hebrew of Isaiah shows the attentive reader that the two seraphim refer to the two Testaments.

This letter argues that Hebrew competence is an essential skill for Christian Biblical reading. It does this by placing the Hebrew language carefully into a Christian economy of time, space and human bodies. The first naming of things was done in Hebrew and by this action human beings came to differentiate themselves from the rest of creation and thereby to understand their place in the economy of the created order. To speak Hebrew was the beginning of creaturehood. The linguistic confusion in which humanity now finds itself affects not merely the everyday exchanges between human beings, but also the relationship between human beings and the Word present in scripture. The gap in understanding is a temporal gap, and to learn Hebrew is to return to that original moment of naming and speaking with the Word. It is also, however, a rupture in human space, for if Babel was a fracture of language, then it was also a breaking apart of human community: from that point forward, humans were scattered over the earth, and the cleavage of human language was reflected in the terrestrial divisions between peoples. Returning to this original language - speaking Hebrew - is not enough to fix humanity, however, for the fulcrum of history is not found at humanity's origin, but at its reconciliation with the Word in the Incarnation. ${ }^{7}$ Knowledge of Hebrew, says Jerome, must be integrated within a wider divine economy of time and space, turning around the body of Christ.

\footnotetext{
${ }^{5}$ Jerome, Epist. 18A.6 (CSEL 54.81.4)

${ }^{6}$ Jerome, Epist. 18A.6 (CSEL 54.82.5). Jerome's source for this reading of human language and the seraphim is Origen: Alfons Fürst, "Jerome keeping silent: Origen and his exegesis of Isaiah," in Jerome of Stridon: His Life, Writings and Legacy, ed. Andrew Cain and Josef Lössl (Farnham and Burlington, VT: Ashgate, 2009); Edmon L. Gallagher, Hebrew Scipture in Patristic Biblical Theory: Canon, Language, Text, Supplements to Vigiliae Christianae (Leiden: Brill, 2012), 133-34.

7 Averil Cameron, Christianity and the Rhetoric of Empire: Towards a Christian Discourse (Oxford and Berkeley, CA: University of California Press, 1991).
} 
Jerome's relationship with Hebrew has been analysed in a large (and growing) body of literature. ${ }^{8}$ This letter comes from the beginning of his career, and over the following three decades he would painstakingly present himself as an authority on Hebrew, mediating its 'truth' to his correspondents in Gaul, Iberia, Italy and North Africa. This translation of Hebrew was not neutral, for it took place in a wider linguistic economy in which language use marked difference and mediated imperial authority. Jerome's translation of the Hebrew Bible into Latin was a controversial project. It both challenged the textual authority of existing Latin translations and asserted Hebrew provenance as a key criterion for canonicity. Jerome's defence of his translation project drew on this wider context, showing how Hebrew could be integrated into this linguistic order. Indeed, he argued, Hebrew offered the principal means of establishing order over diverse Christian biblical readings. Even as he acknowledged the importance of Hebrew, Jerome also positioned it as a challenge to the existing linguistic order of Late Roman society. Hebrew was both the touchstone of a new

\footnotetext{
${ }^{8}$ Gustave Bardy, "Saint Jérôme et ses maitres hébreux," Revue Bénédictine 46 (1934); James Barr, "St Jerome and the Sounds of Hebrew," Journal of Semitic Studies 12 (1967); James Barr, "Saint Jerome's appreciation of Hebrew," Bulletin of the John Rylands Library 49 (1967); Gallagher, Hebrew Scripture; Michael Graves, Jerome's Hebrew Philology: A Study Based on his Commentary on Jeremiah, Supplements to Vigiliae Christianae (Leiden: Brill, 2007); C.T.R. Hayward, Saint Jerome's Hebrew Questions on Genesis (Oxford: Clarendon, 1995); Pierre Jay, "La datation des premières traductions de l'Ancien Testament sur l'hebreu par saint Jérôme," Revue des Études Augustiniennes 28 (1982); Adam Kamesar, Jerome, Greek Scholarship and the Hebrew Bible: a Study of the Quaestiones hebraicae in Genesim (Oxford: Clarendon, 1993); Sarah Kamin, "The theological significance of the Hebraica Veritas in Jerome's thought," in Jews and Christians Interpret the Bible (Jerusalem: Magnes Press, 1991); Matthew Aaron Kraus, "Jerome's Translation of the Book of Exodus Iuxta Hebraeos in Relation to Classical, Christian, and Jewish Traditions of Interpretation " ( $\mathrm{PhD}$, University of Michigan, 1996); Josef Lössl, "A shift in patristic exegesis: Hebrew clarity and historical verity in Augustine, Jerome, Julian of Aeclanum and Theodore of Mopsuestia," Augustinian Studies 51 (2001); Christoph Markschies, "Hieronymus und die Hebraica Veritas: ein Beitrage zur Archäologie des protestantischen Schriftverständnisses," in Die Septuaginta zwischen Judentum un Christentum, ed. Martin Hengel and Anna Maria Schwemer (Tübingen: Mohr Siebeck, 1994); Gianfranco Miletto, "Die 'hebraica veritas' in S. Hieronymus," in Bibel in jüdischer und christlicher Tradition: Festschrift für Johann Maier, ed. H. Merklein, K. Müller, and G. Stemberger, Bonner Biblische Beiträge (Frankfurt am Main: Anton Hain, 1993); Emanuela Prinzivalli, "'Sicubi dubitas, Hebraeos interroga' Girolamo tra difesa dell'Hebraica veritas e polemca antiguidaica," Annali di storia dell'eseges 14 (1997); Stefan Rebenich, "Jerome: The "Vir Trilinguis" and the "Hebraica Veritas"," Vigiliae Christianae 47 (1993); Edmund F. Sutcliffe, "St. Jerome's Pronunciation of Hebrew," Biblica 29 (1948); Steve Weitzman, "Why did the Qumran community write in Hebrew?," Journal of the American Oriental Society 119 (1999).
} 
Christian social, biblical, and cosmic order and, at the same time, a fundamental threat to the processes by which that social, biblical, and cosmic order was reproduced.

This article shows how Jerome integrates Hebrew into wider patterns of late antique masculinity. Jerome's relationship to ancient discourses of manliness has been covered in recent studies which have focussed on the connections between his asceticism and his biblical reading. ${ }^{9}$ As well as providing an important sense of authority to his literary production, Jerome's use of Hebrew also participated in the wider fourth-century play between imperial ideology, Christian triumphalism, and concerted anti-Judaism. ${ }^{10}$ Learning Hebrew was part of Jerome's wider ascetic practice, which he positioned in dialogue with prevailing models of marriage and social order. At the same time, Hebrew sat awkwardly in Jerome's literary production, an element recognisably Jewish and never smoothly integrated into a Christian reading practice. The justifications that Jerome uses to defend his turn to Hebrew are complicated, and that use of Hebrew is itself implicated in manifold currents dancing through late antique society. This article approaches Jerome's mastery of Hebrew through wider, late antique discourses of mastery and masculinity. It does this by thinking about Hebrew as a thing in space. As this article argues, Jerome consistently positions Hebrew language within the space that exists between people communicating. Approaching Hebrew as the thing that fills the 'space in between', this article argues that the best way to think about Hebrew in Jerome is as a species of air, that is, as breath moved and mastered in a particular way. Air, of course, is hard to get a hold of, and this article concludes by showing how it is the very airiness of Hebrew that resists the smooth integration in the Christian economies of time, space, and masculine social order.

Jerome's letter to Damasus, which opened this article, shows how his engagement with Hebrew draws on some important currents in late antique masculinity. To be masculine was

\footnotetext{
9 See, for example, Mathew Kuefler, The Manly Eunuch: Masculnity, Gender Ambiguity, and Christian Ideology in Late Antiquity, The Chicago series on sexuality, history, and society (Chicago: Chicago University Press, 2001), 162-205 and 68-75.

${ }^{10}$ Todd S. Berzon, "The double bind of Christianity's Judaism: language, law, and the incoherence of Late Antique discourse," Journal of Early Christian Studies 23 (2015); Andrew S. Jacobs, Christ Circumcised: A Study in Early Christian History and Difference, Divinations: Rereading Late Ancient Religion (Philadelphia: University of Pennsylvania Press, 2012), 15-19.
} 
to hold mastery over things, particularly wives, children, and slaves. ${ }^{11}$ Mastery over others began with self-mastery, a control of the passions and the body that denoted one's fitness to rule. $^{12}$ In this way, as Chris de Wet has pointed out, discourses of mastery and slavery shaped the way that late antique people imagined themselves in relationship to others. ${ }^{13}$ Jerome's letter is a product of this society and it participated in the wider discursive structures of slavery and mastery in a number of ways. The relationship between human beings and God is torn as a result of offensa, a transgression that offended the honour due to God. ${ }^{14}$ God's action - the violence of exile and destitution - was a response to this offence. Late antique people understood very well the subtle intertwining of linguistic and corporal violence. ${ }^{15}$ To speak shrewdly and to master one's tongue was essential if one was to hold off the brutality of life in the late ancient world. To be a master - in charge, justified in taking offence when slighted, not succumbing to rage - was what defined one as uir. Conversely, to be compelled through persuasion, through physical force, or through one's passions, was to have one's masculinity subverted. Jerome locates the origin of human linguistic diversity in this moment of divine punishment and human abjection. The close connection between human language and masculinised power meant that this letter infused linguistic difference with gendered difference. Like a slave who carries the marks of a flogging, the linguistic diversity of human beings is a shameful trace of innate, unmanly weakness, a welt on the collective hide of humanity that betokens the offence they have done to their master. ${ }^{16}$ Jerome's letter is about power and language, and so it is about masculinity.

\footnotetext{
${ }^{11}$ Mark Masterson has argued that a better model of late antique masculinity is Eve Kosofsky Sedgwick's notion of homosociality. This, he argues, privileges the cooperative nature of elite life, transformed by the senatorial reforms of late antique emperors, see Mark Masterson, Man to Man: Desire, Homosociality, and Authority in Late-Roman Manhood (Columbus, Ohio: Ohio University Press, 2014), 9-12.

${ }^{12}$ Peter Brown, Power and Persuasion in Late Antiquity (Madison, Wisconsin: University of Wisconsin Press, 1992), 50-51; Chris L. de Wet, Preaching Bondage: John Chrysostom and the Discourse of Slavery in Early Christianity (Oakland, California: University of California Press, 2015).

${ }^{13}$ de Wet, Preaching Bondage, 24-25.

${ }^{14}$ Offensa TLL 9.2, 494-495.

${ }^{15}$ Brown, Power and Persuasion, 57-58.

${ }^{16}$ Jennifer A. Glancy, Corporal Knowledge: Early Christian Bodies (Oxford: Oxford University Press, 2010), 30.
} 
The letter also situates language and power as spatial things. A well-ordered society was a coherent image of the well-ordered cosmos, but Babel was an attempt to disrupt this cosmic ordering, to flow over the boundaries that held humans in their rightful place. The linguistic diversity that broke humanity into pieces was a direct consequence of this disruption of cosmic order. ${ }^{17}$ The diversity of human language is reproduced in the diversity of human places, for, after Babel, human beings scattered over the earth. ${ }^{18}$ The spatial distribution of peoples across the world is therefore not accidental, rather it is an index and result of human linguistic diversity. In this letter, human difference began as linguistic difference and, because of this diversity, people can now differentiate the places they live from the territories of other humans. Put simply, language produces space. The inability to communicate - to cross a gap of meaning - produced a spatial difference between peoples. What had been one group, united, became many smaller groups, joined tenuously, articulated, and speaking different tongues. ${ }^{19}$ That humans live in different places and speak different languages is therefore a product of our own incalcitrance and a symptom of a people separated from their creator. In presuming this wider cosmic order, the letter makes implicit claims about the status of human politics. Human diversity is integrated into the wider economy of time and space by which God has set out creation. As a consequence of this, the imperial order of Roman society comes to seem a necessary corrective to the disordering of space in the aftermath of Babel. Jerome's letter simultaneously explains and controls linguistic diversity. Empires are necessary because they temper the catastrophic abundance of human life after Babel. $^{20}$

\footnotetext{
${ }^{17}$ Jeremy M. Schott, "Language," in Late Ancient Knowing: Explorations in Intellectual History, ed. Catherine M. Chin and Moulie Vidas (Oakland, California: University of California Press, 2015), 48-60.

${ }^{18}$ Jerome, Epist. 18A.6 (CSEL 82.6-7): ... tunc sermonis uarietas in omnes dispersa est nationes.

${ }^{19}$ The spatial nature of language - its articulation - is from Jacques Derrida, Of Grammatology, trans. Gayatri Chakravorty Spivak, Corrected ed. (Baltimore, Maryland: Johns Hopkins University Press, 1997), 229-35. See also, Jacques Derrida, "Signature Event Context," in Margins of Philosophy (Brighton, Sussex: Harvester Press, 1982), 311-18. The work of Ika Willis has been helpful in thinking about the connections between Latin, Derrida, and space: Ika Willis, Now and Rome: Vergil and Lucan as Theorists of Politics and Space, Continuum studies in Classical Reception (London: Bloomsbury, 2010), 99-101.

${ }^{20}$ Masterson has argued that it is the space of empire rather than domestic space that is the site at which masculinity is negotiated. In his reading, the primary relationship is not the dominance of one over the other, but a more complicated, homosocial play of cooperation and paideia, see Masterson, Man to Man, 176-77. Some slaves, of course, could move between both spaces. Domestic space and imperial space intersect.
} 
This letter, then, argues for the importance of Hebrew in Christian reading practices. It is also, however, about masculinity and the founding of masculinity in the refusal of transgressive desire; that is, it is a letter about shame. This shame is encountered in the plurality of language, which is a symptom of humanity's disgraceful recalcitrance and it is spatialised in the terrestrial divisions between peoples of the earth. In this context, two theorists offer particularly apt treatments of shame. Frantz Fanon discusses shame in the context of language, while Eve Kosofsky Sedgwick reads shame as a spatial affect.

Combining these two authors produces a good set of tools to read Jerome's engagement with Hebrew, which will take up the final portion of the article. The spatial nature of Sedgwick's analysis of shame is a useful addition to Fanon, because it makes more visible the spatial play in Fanon's analysis. As I'll show below, Fanon's critique of shame depends on a particular attention to breath as something that moves through space to cross the racialised frontiers of bodies and language. Using this model of shame, in the final part of the article I track Jerome's use of Hebrew. A focus on breathy shame reveals the ways that Hebrew is drawn into wider discourse of masculine embodiment and also indicates why it refuses complete integration in a Christian imperial economy of time, space, and speaking humans.

\section{2: LANGUAGE, SHAME, AND HUMAN DIVERSITY}

Shame is a social phenomenon. ${ }^{21}$ Studies of early Christianity have drawn on theorisations of shame from poststructuralist thinkers and noted that shame could be effectively marshalled by late antique Christians because it held a prominent place in the affective register of the late antique world. ${ }^{22}$ Shame, and other affects, also shapes the modern production of knowledge about that ancient Christian past. ${ }^{23}$ In Jerome's case, as I have suggested, human language itself became a site suffused with shame. One theorist of shame who can be profitably used to analyse early Christianity is Frantz Fanon. This is because language and shame are

\footnotetext{
${ }^{21}$ Elizabeth A. Clark, "Sex, shame, and rhetoric: en-gendering early Christian ethics," Journal of the American Academy of Religion 592 (1991): 228.

${ }^{22}$ Carly Daniel-Hughes, ""Wear the armor of your shame!": debating veiling and the salvation of the flesh in Tertullian of Carthage " Studies in Religion/Sciences Religieuses 39 (2010); Chris L. de Wet, "Claiming corporeal capital: John Chrysostom's Homilies on the Maccabean Martyrs," Journal of Early Christian History $2(2010)$.

${ }^{23}$ Maia Kotrosits, "Romance and danger at Nag Hammadi," The Bible and Critical Theory 8 (2012).
} 
fundamental parts of Fanon's attempt to grapple with human diversity and the racism of European humanism. ${ }^{24}$

In Black Skin, White Masks, Fanon's critique of colonial racism draws heavily on the phenomenology of Husserl and Heidegger, as mediated through Merleau-Ponty. ${ }^{25}$ Sensations from within and outside the body form a corporeal schema through which Fanon is placed in the world. This schema is disrupted through the call of a child who identifies Fanon: 'Tiens, un nègre!'. 26 "The corporeal schema collapsed, giving way to an epidermal racial schema," as he puts it. ${ }^{27}$ Shame, in the Sartrean sense that influenced Fanon, is the apprehension of the self-as-object, and the moment in which Fanon is named 'un nègre' in the speech of the child is the moment in which he feels shame. ${ }^{28}$ This sense of being-for-the-other is the centre-point of Fanon's critique of racism, to which he responds by putting forward 'a humanism of solidarity' influenced by Sartre's discussion of anti-semitism. ${ }^{29}$ In response to a racism in which the gaze of the other effaces his humanity, he proposes a humanity which is 'a residual category without content, and signifies only a fundamental ethical need for recognition of the dignity and autonomy of the other. ${ }^{30}$ Shame and language are the tools by which Fanon breaks open the universal that underpins the racism of European humanism. ${ }^{31}$

Key to this argument is the discussion of language, difference and power that takes up a large portion of Black Skin, White Masks. In one passage, he rejects the assertion that people from

\footnotetext{
${ }^{24}$ For a view, contemporary with Fanon, that connects the humanism of post-war Europe to the early Church, see Henri Marrou's address to the 1951 Oxford Conference, Henri-Irénée Marrou, "Patristique et humanisme," in Patristique et humanisme: mélanges par Henri-Irénée Marrou, Patristica Sorbonensia (Paris: Éditions de Seuil, 1976).

${ }^{25}$ David Macey, Frantz Fanon: A Biography, Second ed. (London and New York: Verso, 2012), 162-63.

${ }^{26}$ Frantz Fanon, Peau noire, masques blancs (Paris: Éditions du Seuil, 1952), 90.

${ }^{27}$ As cited in Macey, Frantz Fanon, 163.

${ }^{28}$ Macey, Frantz Fanon, 164-65.

${ }^{29}$ Fanon, Peau noire, masques blancs, 167.

${ }^{30}$ Jane Hiddlestone, Decolonising the Intellectual: Politics, Culture, and Humanism at the End of the French Empire, Contemporary French and Francophone Cultures (Liverpool: Liverpool University Press, 2014), 135.

${ }^{31}$ Gordon on Hegel and Fanon: 'A people's greater universality or their greater particularity is contingent on their closeness to whiteness ...'Lewis R. Gordon, "Fanon, philosophy, racism," in Racism and Philosophy, ed. Susan E. Babbitt and Sue Campbell (Ithaca, New York: Cornell University Press, 1999), 34.
} 
Martinique lack the capacity to speak French properly. Fanon recalls a story that he hopes will teach his readers about empire, linguistic diversity, and how to become a whole human being: ${ }^{32}$

It has been said that the orators of the Antilles have a power of expression that would leave any European panting. I am reminded of a relevant story: in the election campaign of 1945, Aimé Césaire, who was seeking a deputy's seat, addressed a large audience in the boys' school in Fort-de-France. In the middle of his speech a woman fainted. The next day an acquaintance told me about this and commented: "French so exciting that the woman passed out." The power of language! ("Français a té tellement chaud que la femme là tombé malcadi." Puissance du langage!) $)^{33}$

As with elsewhere in the book, Fanon rejects inauthenticity that stems from being-for-theother and offers a radically open-ended view of the human based on evidence drawn from lived experience in the world. ${ }^{34}$ This section begins with the claim that the Antillais orator has the capacity to leave Europeans 'panting' (... qui laisserait pantelants les Européens). ${ }^{35}$ Then Fanon describes Césaire's facility with French, saying that it made 'the woman' pass out. 'Pass out' here is a rough translation of from Antillais French: malcadi. The Antillais word derives from an old French word for epilepsy (le mal caduc) and so it also means to tremble or shudder, with a connotation of jouissance. Fanon clearly thinks that his readers won't know this word, for he glosses this passage with a footnote to his readers, explaining that malcadi means 'la femme est tombée en trances.' 36

This passage is a joke. Fanon argues that the Antillais speaks true French, but does this through a colloquialism that has to be glossed and translated for his metropolitan readers. The

\footnotetext{
32 "Tâchons d'inventer l'homme total que l'Europe a été incapable de faire triompher" Frantz Fanon, Les damnés de terre, 2002 ed. (Paris: La Découverte, 1961), 302. Tr. "Let us try to create the whole human being, whom Europe has been incapable of bringing to triumphant birth," from Gordon, "Fanon, philosophy, racism," 49.

${ }^{33}$ Fanon, Peau noire, masques blancs, 30-31.

${ }^{34}$ Macey, Frantz Fanon, 166.

${ }^{35}$ Fanon, Peau noire, masques blancs, 30.

${ }^{36}$ Fanon, Peau noire, masques blancs, 31, n.12.
} 
effect is double: as Césaire's speech makes the woman pant and pass out, so Fanon's play between Antillais and Metropolitan French makes the reader laugh. Breath is interrupted in both cases, and so Antillais French evinces its capacity to leave Europeans panting. ${ }^{37}$ As Jane Hiddlestone has remarked, this kind of movement recurs throughout Fanon's text and can be read as a more-or-less explicit staging of the francophone intellectual's alienation. ${ }^{38}$ In a Sartrean sense, this eruption of laughter signifies the shame that is experienced when one is apprehended as object. But in this passage, Fanon moves beyond a Sartrean sense of shame and begins to approach an understanding of shame as spatial.

In her analysis of space and affect, Sedgwick says that one of the most useful aspects of shame for unlocking identity is the way that it shows identity as performed relationally, between people and across spaces, remaining always 'to-be-constituted'. ${ }^{39}$ She thereby argues that the performance of shame is a fundamentally political act, without reducing identity to an essence. ${ }^{40}$ Identity is performed spatially. While poststructuralist accounts of identity (e.g. Derrida; Butler) have emphasised the intricate temporalities of identity (foregrounding e.g. memory; performative repetition), Sedgwick argued that applying spatial thinking opens up new 'neighbourhoods' of enquiry. ${ }^{41}$ A scene of interlocution, for example a moment when someone says 'I dare you,' presupposes a singular subject that speaks and a singular object who is addressed. Such performative utterances, are, however, surrounded by a host of things that Sedgwick terms 'periperformatives': the witnessing of that utterance by a third party; the

\footnotetext{
${ }^{37}$ Jane Hiddlestone, "The perplexed person of Frantz Fanon's Peau noire, masques blancs," Postcolonial Text 4 4 (2008): 8. When Fanon committed to publishing Peau noire, masques blancs with Éditions du Seuil he was making an important choice. He could, for example, have followed the example of Placide Tempel's La philosophie bantou (1947) and published the book with Presence africaine. But Fanon had already published work in the journal Ésprit, and by placing his monograph in their series "La condition humaine" a careful point was being made. In the early 1950s, Fanon was trying to articulate a truly universal humanism in response to the humanisme colonial that had directed the colonial policies of the Third Republic. The choice of publisher, the journal and its series, reflects Fanon's determination to position his work within the wider French republican humanist tradition. See Macey, Frantz Fanon, 155-58.

${ }^{38}$ Hiddlestone, "The perplexed person," 14.

${ }^{39}$ Eve Kosofsky Sedgwick, Touching Feeling: Affect, Pedagogy, Performance (Duke University Press, 2003), 64.

${ }^{40}$ Sedgwick, Touching Feeling, 64.

${ }^{41}$ Sedgwick, Touching Feeling, 68.
} 
implicit opportunity of refusal that the utterance offers; words about that performative utterance; the establishment and fracturing of a relationality between interlocutors; ${ }^{42}$ the hiding and ascribing of agency to persons and objects. ${ }^{43}$ Periperformatives are the frame which governs performative acts. They draw groups into an 'ecological field' of relationality in which performance can be understood and identity can be constituted. ${ }^{44}$ Beside every explicit performative utterance, then, is a wider, knotty network of periperformatives, running alongside, beneath and between the performative. In its tangency to the explicit, the periperformative is the space in which ways of relating emerge that are queer, that run beside and between the straight and explicit. Making the periperformative visible requires an attention to the spatial nature of performative utterances; their location at specific points in space and time. ${ }^{45}$

Sara Ahmed has noted that '[s]paces acquire the 'skin' of the bodies that inhabit them. ... Spaces also take shape by being orientated around some bodies, more than others. ${ }^{46} \mathrm{We}$ might say that spaces have an epidermal schema. In the passage on Césaire's speech, Fanon works to present the European as object, to make whiteness visible. ${ }^{47}$ In particular, it is the arrested breath of the woman and the reader which mark them as European to the Antillais, for it is this moment of shame which is the origin of the laugh - the interrupted breath - for both Fanon and his reader. In the school hall recalled in Fanon's words, a host of periperformatives cluster around the suggestion that Antillais cannot speak French: Césaire's exciting speech; the recounting of that speech to Fanon; Fanon's account to his readers. But key to the force of Fanon's account is the periperformative role played by breath as it is invoked and then manipulated. Using breath's relationship to French, Fanon does not shy away from shame, but rather draws his reader into it and then uses that experience of shame to constitute a shared humanity between himself and his metropolitan, European readers. The periperformative quality of breath means that shame is not only a symptom of alienation, as in Sartre, but is instead a productive site in which Fanon can refuse European readings of

\footnotetext{
${ }^{42}$ Sedgwick, Touching Feeling, 72-73.

${ }^{43}$ Sedgwick, Touching Feeling, 77.

${ }^{44}$ Sedgwick, Touching Feeling, 9.

${ }^{45}$ Sedgwick, Touching Feeling, 68.

${ }^{46}$ Sara Ahmed, "A phenomenology of whiteness," Feminist Theory 8 (2007): 157.

${ }^{47}$ Steve Garner, Whiteness: An Introduction (Abingdon: Routledge, 2007), 50-51.
} 
Antillais French, opening up a radical humanism and a new relationality beyond the racialised boundaries of the 'epidermal schema'. This site becomes visible, readable, in the interruptions of smoothly ordered breath shared by Fanon, the European woman and the reader. ${ }^{48}$ Breath, in its periperformative relationship to utterances about Antillais French, is the spatial site in which shame is encountered and a new politics can be imagined.

Shame is relational and so was bound into the master-slave discourse that grounded the political in late antique space. Fanon, like Jerome, responded to human diversity by tracing connections between language, shame, and masculinity. In Fanon's model, one way of making this intersection visible is by focusing on the movement of air as it circulates among the crowd and the readers. Sedgwick took shame's relationality seriously, envisioning it as a spatial affect which had the potential to ground radically new ways of relating to others. This potential lies in shame's capacity to dissolve the boundaries between inside and outside, to traverse, like breath, the boundary line differentiating human beings. Taking its cue from Fanon and Sedgwick, this paper reads Jerome's account of masculinity, shame, and language by tracing the way that Jerome thinks about air and language. In what remains of this article, I will first approach Jerome's use of Hebrew through Sedgwick, as something that disrupts or runs alongside the social relationships that constitute late antique masculinity, that is, as something productively shameful. Then I will approach Hebrew as a species of air, showing how its circulation between the inside and outside of Jerome's body participates in discourses of late antique masculinity, but refuses to be reduced to them.

\section{3: HEBREW DISRUPTS SOCIAL RELATIONSHIPS}

Eve Kosofsky Sedgwick described shame as entailing a 'double movement' between individuation and relationality. ${ }^{49}$ It is the periperformative that establishes the relational and individuating effects of shame. Shame is spatial, emerging in the space that is observed by a third party, in the comments on another's utterances. This focus on shame and the periperformative can be profitably used to unpick the connection between Hebrew and masculinity. Indeed, 'double movement' would be an apt description of Jerome's relationship with Hebrew. In the beginning, speaking Hebrew showed human beings their relationship

\footnotetext{
${ }^{48}$ As Ahmed says, "Whiteness is an effect of what coheres rather than the origin of coherence ... what is repeated is a very style of embodiment, a way of inhabiting space ... whiteness allows bodies to move with comfort through space ...' Ahmed, "A phenomenology of whiteness," 159.

${ }^{49}$ Sedgwick, Touching Feeling, 37.
} 
with God and brought them into knowledge of their creaturehood. At the same time, Hebrew is the principal means by which Jerome could differentiate himself from other Latin-speaking Christians. Space, and the traversing of space by language, features prominently in Jerome's discussion of Hebrew as well. Hebrew is something that runs beside the exchange of Latin words and, in so doing, it disrupts the spaces between people, making new social ties in the process.

For example, a letter from Jerome to Marcella offers 'big and necessary' reasons for a gap in his correspondence with her. ${ }^{50}$ Jerome has been comparing a Greek version of the Hebrew Bible with the Hebrew version, apparently to check whether 'the synagogues' have altered the Greek. ${ }^{51}$ 'You see, then,' he says, 'that no duty can come before this work.' ${ }^{52}$ At the conclusion of this letter Jerome asks after Marcella's mother and attaches to this note two other letters presumably for her to mark up and then read. ${ }^{53}$ The letter therefore depicts Jerome as a key part of a wider circle of patrons and admirers and at the centre of a wellordered society of Roman men and women. ${ }^{54}$ In a move of Christian anti-Judaism, mastery of Hebrew granted Jerome a mastery over the synagogues and their textual production. Despite fulfilling this 'duty', the letter to Marcella was written to cover an absence: a 'gift of epistolary conversation' that Jerome had failed to deliver to Marcella, his patron. ${ }^{55}$ Jerome's philological labour on Hebrew has interrupted the normal epistolary exchange between patron and client. ${ }^{56}$ As he presents it, however, his obligations to his patron are superseded by his duty (officium) to maintain the order of scripture in the face of the "hatred of the synagogues'. ${ }^{57}$ Hebrew, then, is integrated into the economy of status and patronage that offers the context for Jerome's literary production. Like all literary productions, this one

\footnotetext{
${ }^{50}$ Jerome, Epist. 32.1 (CSEL 54.252.5-6): ... quidnam illud sit tam grande tam necessarium...

${ }^{51}$ Jerome, Epist. 32.1 (CSEL 54.252.7-9)

${ }^{52}$ Jerome, Epist. 32.1 (CSEL 54.252.13-14): Vides igitur, quod nullum officium huic operi praeponendum est.

${ }^{53}$ Epist. 30 and 31. Kim Haines-Eitzen, The Gendered Palimpsest: Women, Writing, and Representation in Early Christianity (New York: Oxford University Press, 2012), 45-46.

${ }^{54}$ Cain, Letters of Jerome, 85-86.

${ }^{55}$ Jerome, Epist. 32.1 (CSEL 54.252.6-7): ... epistolicae confabulationis munus ...

${ }^{56}$ Cain, Letters of Jerome, 85-6.

${ }^{57}$ Jerome, Epist. 32.1 (CSEL 54.252.8-9): ... ne quid forsitan propter odium Christi synagoga mutauerit ...
} 
binds author and reader into networks of responsibility and obligation, but in this case the turn to Hebrew interrupts the established confabulatory economy between Latin speakers.

This theme recurs in a letter from the early 380 s between Jerome and Damasus. ${ }^{58}$ As Jerome's patron, Damasus would have expected work to be produced for him; Jerome bore a responsibility to write. In this letter Jerome presents himself on the cusp of dictating a response to an earlier letter of Damasus ( $E p$. 35) when he is interrupted by 'a Hebrew' who has taken books from the synagogue so that Jerome might transcribe them:

After receiving (accepi) your holiness's letter, I summoned the secretary and commanded him to listen (exciperet imperaui). So there I was, with my station prepared, with voice ready, before I had given colour to my thought. As we began to stir, I the tongue and he the hand, suddenly a Hebrew arrived bringing no little quantity of books, which he had taken from the synagogue as if to read. Immediately he said 'Take what you asked for!' ... I skipped over everything that I was going to write so that I might fly over them ... 59

This opening is a deliberate rhetorical set-piece. ${ }^{60}$ Jerome's presentation of himself at work highlights the media necessary for literary production: the voice, the hand, the secretary. ${ }^{61} \mathrm{~A}$

58 Pierre Nautin, "Le premier échange épistolaire entre Jérôme et Damase: lettres réelles ou fictives?," Freiburger Zeischrift für Philosophie und Theologie 30 (1983) argues that the exchange was concocted by Jerome after Damasus' death, but Cain's argument for authenticity is persuasive Cain, Letters of Jerome, 56-58. See also Alfons Fürst, Hieronymus: Askese und Wissenschaft in der Spätantike (Freiburg: Herder, 2003$), 67$. Whether the exchange is a fiction or not, it remains a good indication of how Jerome sought to position his engagement with Hebrew within his wider literary production.

59 Jerome, Epist. 36.1 (CSEL 54.268.4-268.12): postquam epistulam tuae sanctitatis accepi, confestim accito notario, ut exciperet, imperaui; quo ad officium praeparato, quod eram uoce prompturus, ante mihi cogitatione pingebam. interim iam et ego linguam et ille articulum mouebamus, cum subito hebraeus interuenit deferens non pauca uolumina, quae de synagoga quasi lecturus acceperat. et ilico 'habes', inquid, 'quod postulaueras'... ut omnibus praetermissis ad scribendum transuolarem ...

60 Andrew Cain, "In Ambrosiaster's shadow: a critical re-evaluation of the last surviving letter exchange between Pope Damasus and Jerome," Revue des Études Augustiniennes 512005 (2005); Cain, Letters of Jerome, 57-62.

${ }^{61}$ Jerome, Praef. in Hom. Orig. in Jer. et Hiez (PL 25.585A). Megan Hale Williams, The Monk and the Book: Jerome and the Making of Christian Scholarship (Chicago, IL and London: University of Chicago Press, 2006), 211-14. 
clear economy of literary production is established as accipere becomes excipere: Damasus writes to command, which generates Jerome's command to the secretary and the creation of more words. As the voice stirred, said Jerome, so did the pen. Into this scene of productive harmony irrupts the hebraeus. Jerome's relationship with Damasus, conducted through the voice and the pen, is now held in suspension as the more immediate responsibilities to the Hebrew text take precedence. As in other work produced by Jerome during his time in Rome in the early 380s, reading and writing binds Jerome into networks of responsibility, both to Damasus and to the Hebrew. In this case, however, the stable conjunction of Damasus, Jerome and the secretary is interrupted. Jerome shows how Hebrew can be integrated into a wider Christian economy of literary production, but this integration is disruptive. ${ }^{62}$

In the two examples just presented Hebrew shapes the material production of words and is part of the economy of literary production, but is never completely subsumed within it. This is a recurrent character of Jerome's discussion of Hebrew. In the two cases just cited he writes about vocal communication, calling a letter exchange a confabulatio or (more obviously) describing the words that passed around the workstation. Each of these performances of speaking is primarily spatial. It takes place between interlocutors, and each also places these utterances within a wider field of periperformatives, beside whom the exchange is performed. Marcella is addressed in the letter, but the synagogues intervene in Christian reading. Jerome commands the secretary and then is commanded in turn by 'the Hebrew,' a conversation that is reported to Damasus. In these letters, working with Hebrew is not a single act, but rather a collection of spatial relationships drawn together around the site of reading. While Hebrew disrupts the ordered structures of patronage that bind Jerome and his correspondents together, it also produces new relationships built around obligation and responsibility.

Perhaps the best way to understand what's going on here is to return to those few lines about Babel that began this article. ${ }^{63}$ In that passage, the diversity of human language is a response to transgression. There would, therefore, always be something shameful about crossing linguistic boundaries. The letters to Marcella and to Damasus show how the study of Hebrew is itself transgressive, breaking the ties of responsibility and duty that bind Jerome to his

\footnotetext{
${ }^{62}$ Pierre Macherey, A Theory of Literary Production, trans. Geoffrey Wall, New 2006 ed. (London: Routledge and Kegan Paul, 1978), 146-47.

${ }^{63}$ Jerome, Epist. 18A.6
} 
patrons. These scenes expand the arena of linguistic performance to include the periperformatives and, in so doing, definitions of community, politics and society are reformed. These scenes of reading individuate Jerome, separating him from his secretary and his patrons, and they bind him into different relationships of responsibility and duty (officium). His study of Hebrew can be read through Sedgwick's account of shame and the formation of queer identity. ${ }^{64}$ This recognises how the speaking of Hebrew takes place within a wider field in which crossing linguistic boundaries returns one to the original site of shameful transgression at Babel. The two scenes of Hebrew reading that we see in Jerome's letters to Marcella and Damasus show how Hebrew disrupts the ordered production of letters and (therefore) the reproduction of social ties. Instead, Jerome presents Hebrew as something queer. It exists alongside the ordered reproduction of Roman society and cannot be smoothly integrated within it. Instead, it posits something recognisably social-structured around relationships of obligations and responsibility - but a social that complicates the ordered reproduction of masculinity in the patron-client relationship.

\section{4: HEBREW IS A KIND OF AIR}

In the letters to Marcella and Damasus just discussed, Hebrew is positioned in relationship to wider models of literary patronage and social reproduction. Both of these letters present Hebrew as something that traverses space, either in the carrying of scrolls through a city, the movement of epistles between hands, or the speaking of words around a work station. As Hebrew is spoken, then, it also reforms that space, immersing it within new social bonds of responsibility and obligation. Attending to the spatiality of Jerome's Hebrew invites us to think about the medium through which that language travels: air. Reading Hebrew as something that reconstitutes space as it travels through it requires attention to Hebrew as a kind of air. Indeed, the very airiness of Hebrew gives it a particular status in Jerome's wider economy of literary production.

That language was a kind of air was a familiar position in late antiquity. For late ancient authors like Jerome, the voice and the written word intertwined: one must pronounce in order to parse text, to write is to speak. As Shane Butler has put it, the written text existed 'not in

\footnotetext{
${ }^{64}$ On 'queer' as a descriptor of late antique Christianity, see Virginia Burrus, Saving Shame: Martyrs, Saints and Other Abject Subjects (Philadelphia: University of Pennsylvania Press, 2008), 13.
} 
spite of voices, nor even for the voice's sake, but as voice, written. ${ }^{, 65}$ That letters were a written voice is clearly expressed by Donatus, Jerome's teacher:

A uox is air that has been struck and which, barring other factors, can be heard. Every uox is either articulata or confusa. A uox articulata is one that can be captured (conprehendi) by the letters of the alphabet; a uox confusa is one that cannot be written down. The letter is the smallest element of articulated sound. Some letters are vowels, some are consonants. ${ }^{66}$

The distinction that Donatus makes is between noise (uox) that can be split into articulated 'chunks' of sound that can be rendered in writing (uox articulata) and noise that is mere sonic melange (uox confusa). Donatus imagines that the letters written on a page correspond directly to the spoken sounds that make up a language and that animal sounds cannot be written down because these uoces do not map onto the letters of written language. ${ }^{67}$ This discussion of uox is similar to one put forward by Varro, who also says that the Stoics think the uox articulata is rational and the uox confusa is irrational. ${ }^{68}$ Although the specifically Stoic elements have been discarded in Donatus' distinction of the uoces,${ }^{69}$ there remains a sense that all uoces can be divided into things ordered - written language - or disordered. Like humanity itself after Babel, human language is split into smaller pieces that can be captured, moved around, and tenuously re-joined. It is articulated. The transfer of voice to page was not neutral, then, but carried implicit assumptions about the nature of voice, the

\footnotetext{
${ }^{65}$ Shane Butler, The Ancient Phonograph (Zone, 2015), 26.

${ }^{66}$ Ael. Donatus Ars Mai. 1.1-2 (Holtz p.603, GL 4.367; tr. Butler p.112-113, with changes): uox est aer ictus, sensibilis auditu, quantum in ipso est. omnis uox aut articulata est aut confusa. articulata est, quae litteris conprehendi potest; confusa, quae scribi non potest. littera est pars minima uocis articulatae. Litterarum aliae sunt vocales, aliae consonantes.

${ }^{67}$ Blair Sullivan, "The unwritable sound of music: the origins and implications of Isidore's memorial metaphor," in The Echo of Music: Essays in Honor of Marie Louise Göllner, ed. Blair Sullivan (Warren, Michigan: Harmonie Press, 2004), 41.

${ }^{68}$ Varro, Gramm. Romae fragmenta 268 (tr. Sullivan p.42): Articulate sound is rational, clearly pronounced in human speech. It is also called literate or writable because it can be composed with letters. Undifferentiated sounds is irrational and unwritable, present in the natural sounds of the voices of animals (Articulata est rationalis hominum loquellis explanata. Eadem et litteralis appellatur, quia litteris conprehendi potest. Confusa est inrationalis vel inscriptilis, simplici vocis sono animalium effecta. qiae scribi non potest...)

${ }^{69}$ M. L. Colish, The Stoic Tradition from Antiquity to the Early Middle Ages, 2 vols. (Leiden1985), 326.
} 
language that it carried, and the place of that language in the wider linguistic order of the late ancient world. While a uox can be ordered or disordered, every uox is by definition 'struck air' (aer ictus).

Approaching Hebrew as a particular kind of air invites us to return once more to the aftermath of Babel and its division of languages and bodies. In a world of diversity and division, air drifts across borders. Ancient oratical and medical textbooks connect deep breathing to masculinity; women and children have higher voices because they circulate smaller volumes of air. ${ }^{70}$ Aristotle wrote the human foetus was made in the womb by moving breath inside and outside of its body; breathing was the beginning of all human life. ${ }^{71}$ More recent treatments have continued to focus on this aspect of breath. As Jean Christophe Bailly has observed, the backwards and forwards movement of air that we call respiration is a movement between the inside and the outside of the body. Attending to breathing shows us that life depends on - clings to - a gossamer thread joining us to the outside air and that 'living is immediately constituted and produced, until the end, as a porosity." ${ }^{, 2}$ Air, like Hebrew, is the beginning of creaturehood. It is something shared by all living things, passed through and between bodies. Air precedes thought, indeed, it must be consumed in order for the hot human brain to cogitate, imagine, and make sense of the world. ${ }^{73}$ Despite the opinions in ancient medical textbooks, the ubiquity of air for all life suggests something before discursively-produced bodily differences of gender, race, age, ability: an anoriginal (already present) flesh that absorbs and exhales the world. ${ }^{74}$

One of the places in which we can listen to the air of Jerome's Hebrew is when he emphasises the difficulty of translation. In these moments, Jerome's interest in spoken Hebrew cannot be separated from his interest in the Hebrew letters that capture it. ${ }^{75}$ In a

\footnotetext{
${ }^{70}$ Maud Gleason, Making Men: Sophists and Self-Presentation in Ancient Rome (Princeton University Press: Princeton, New Jersey, 1995), 82-103.

${ }^{71}$ Johanna Stiebert, "Human conception in antiquity: the Hebrew Bible in context," Theology and Sexuality 16 (2010): 214.

72 Jean-Christophe Bailly, "The Slightest Breath (On Living)," The New Centennial Review 10 (2010): 4-5.

73 Ashon T. Crawley, "Breathing flesh and BlackPentacostalism," Theology and Sexuality 19 (2013): 50.

${ }^{74}$ Crawley, "Breathing flesh," 55; Ashon T. Crawley, BlackPentacostal Breath: The Aesthetics of Possibility (New York: Fordham University Press, 2017), 59.

${ }^{75}$ Barr, "St Jerome and the Sounds of Hebrew," 6-7; Graves, Jerome's Hebrew Philology, 30.
} 
period before punctuation, the correct pronunciation of words was important if one was to parse a text correctly. ${ }^{76}$ Jerome says that Hebrew has a distinctively ambiguous character; there is a forest of different possible meanings for each word and "when each [reader] appears in doubts then consequently each translates according to himself' (dum unusquisque inter dubia quod sibi consequentius uidetur, hoc transfert). ${ }^{77}$ The deployment of Jerome's Hebrew knowledge is intended to stabilise particular ambiguities in reading scripture. For example in his late Commentary on Jeremiah he notes that:

In place of 'watching rod,' the LXX translated 'nut-tree staff.' We must therefore elaborate on the matter, so that the Latin reader may understand the Hebrew etymology. In Hebrew the word 'nut-tree' is saced, whereas the Hebrew word for 'a watch' or 'watchful' is soced. ${ }^{78}$

Here Jerome amends the Greek translation, pointing out that Jer. 1:11-12 includes a play on words. ${ }^{79}$ This is not clear from the written Hebrew text in front of him because the lack of vowel markings mean that there are a number of different ways in which the word might be translated. ${ }^{80}$ Vocalising the words allows one better to parse the text and Jerome resolves the Greek mistranslation by transliterating the Hebrew into Latin letters, making the vowel sound clearer. This translation process - this movement across linguistic borders - can only be accomplished by the vocalisation of the letters and the forcing of air through the throat and mouth. The utility of contemporary Hebrew speech lies in its ability to clarify portions of the historical account preserved in Hebrew writing and so 'pronunciation is an act of interpretation. $^{, 81}$

\footnotetext{
${ }^{76}$ Donatus, Ars Maior (Holtz 610, GL 4.371): accentuum legem uel distinguendi uel pronuntiandi ratio uel discernendae ambiguitatis necessitas saepe conturbat. The grammatical importance of lectio to Jerome's Hebrew is discussed in Graves, Jerome's Hebrew Philology, 26-35.

${ }^{77}$ Jerome, Ruf. 1.20 (CCSL 79.20)

${ }^{78}$ Jerome, Comm. Jer. 1.11-12.2 (CCSL 74.7-8) Barr, "St Jerome and the Sounds of Hebrew," 36.

${ }^{79}$ Jerome, Comm. Jer. 1:11-12.2 (CSL 74.7)

${ }^{80}$ Jerome, Comm. Jer. 25:26.2 (CCSL 74.245-246)

${ }^{81}$ Graves, Jerome's Hebrew Philology, 30.
} 
This translation process presents another problem, however, particularly for a late antique understanding of language. The uox of Hebrew is imperfectly captured by Latin letters. ${ }^{82}$ Hebrew is ambiguous in character: while Hebrew remains articulatus, the letters of the language do not fully capture or master the airy uox. Language learning in late antiquity was relational for, by mimesis, it inducted the student into wider notions of well-ordered speaking and social behaviour. ${ }^{83}$ The character of Hebrew, however, means that it resists this relationality, drawing each person to struggle by themselves and to produce a translation governed not by the authority of the ancients but by 'oneself.' Working in Hebrew forces one to work heavily through the air-filled mouth, but this produces a uox that sits awkwardly within the world of late antique language, suspended between the ordered spacing of mastery and articulation, and the mixed-up, anarchic conglomeration of uox confusa.

Perhaps it is because of Hebrew's airy ambiguity that Jerome tells us that speaking Hebrew sat awkwardly in his linguistic world. In 412 he wrote a letter to a young monk and remembered that his introduction to Hebrew was born of a desire to control his sinful mind:

To bring [my mind] under control, I made myself the pupil of a Christian convert from Judaism. After the subtlety of Quintilian, the flowing eloquence of Cicero, the dignified prose of Fronto, the smooth grace of Pliny, I set myself to learn an alphabet and strove to pronounce hissing, breath-demanding words. ${ }^{84}$

Jerome incorporated Hebrew into an ascetic regimen focused on the disciplining and mortification of the body: the hissing sounds are harsh to Latin ears, the throat pants. ${ }^{85}$ In this passage, Jerome imagines two groups, organised according to language: 'the Latins' and 'the Hebrews'. Moreover, as intimated in a much earlier letter from the deserts around Antioch, the immersion in a foreign language wears away at the subtleties of Jerome's Latin style,

\footnotetext{
${ }^{82}$ Catherine M. Chin, Grammar and Christianity in the Late Roman World (Philadelphia: University of Pennsylvania Press, 2008), 98-99.

83 Tim Whitmarsh, Greek Literature and the Roman Empire: The Politics of Imitation (Oxford: Oxford University Press, 2001), 128-29.

${ }^{84}$ Epist. 125.12; tr. Kelly 50.

${ }^{85}$ Patricia Cox Miller, "The blazing body: ascetic desire in Jerome's letter to Eustochium," Journal of Early Christian Studies 1 (1993): 37-38.
} 
eroding the very foundations of his status as a member of the cultural elite. ${ }^{86}$ Speaking Hebrew is hard, but speaking Hebrew also erodes the carefully crafted verbal edifice that fixes Jerome as a Latin speaker in the world of late antiquity, breaking the 'discrete discipline' that binds him to Latin society. ${ }^{87}$

This is present in the words that Jerome uses to describe the play of air as he speaks Hebrew. The phrase translated as 'to pronounce hissing, breath-demanding words' here might more literally (less elegantly) be translated as 'to pronounce hissing and having-to-be-gasped words.' (stridentia anhelantiaque uerba meditarer). The two groups here are defined not merely by their linguistic affiliation, but by the way they move air in the act of speaking. Cicero's flow and Pliny's grace contrast with the back-and-forth hiss and gasp of Hebrew. In this passage, air - and particularly the movement of air in breath - is what marks the difference between Latin and Hebrew. Because this is an air that moves through the mouth, it also makes visible the flesh of the mouth as Latin or Hebrew body. Thus discursively produced, the body is embedded in networks of power and obligation, either to the authors who provide the archetypes of Latin language ${ }^{88}$ or to the $u o x$ of Hebrew which escapes from its letters to demand its sacrifice of gasping breath.

Hebrew is uox and is therefore constituted in the play of air across Jerome's gullet, over his tongue and between his teeth. Recognising this means that we also observe flesh in the process of becoming body. We see how life in its abundant potential becomes regulated and socially-visible. As air-passing thing, the body becomes a site in which the power of language plays out, either in the debt one owes to the archetypes of Latin speaking or in the demands that Hebrew makes on one's breath. Jerome shows us in his commentary on Jeremiah that speaking Hebrew is also the process by which the ambiguous potential of Hebrew letters becomes the sure and certain meanings of Christianity. Those things which lie beside the written word - speech, body, other agencies, air, other periperformatives - are stripped away. Bailly remarks that living is constituted as porosity, and this indicates why air is a potentially productive way of approaching Jerome's Hebrew. In Late Antiquity, to speak well was to

\footnotetext{
${ }^{86}$ Jerome, Epist. 29.7 (CSEL 54.242.3) Williams, The Monk, 61.

${ }^{87}$ Peter Brown, The Body and Society: Men, Women and Sexual Renunciation in Early Christianity (New York: Columbia University Press, 1988), 31.

${ }^{88}$ Chin, Grammar and Christianity, 20-23.
} 
situate oneself within the social body and to take one's appropriate place in the power relationships of empire. Hebrew endangers that order, for the speaker of Hebrew is constituted not in relation to the authorities of Latin (e.g. Quintilian; Cicero) but in relation to the language of Hebrew itself. This is presented by Jerome as a gasping, an entry into the inner spaces of the male body by language-bearing air. The male speaker is dependent on that which he ought to control. Ordered society breaks down and "consequently each translates according to himself". Hebrew is uox - struck air - and attending to the movement of air across space, between and within bodies, reveals the ways that Hebrew is assimilated to, and disrupts, the imperial order of the later Roman Empire.

\section{5: AIR-POWER}

Fanon recognised the link between air and power ("Français a té tellement chaud que la femme là tombé malcadi." Puissance du langage!). A new politics can be imagined when the play of air around flesh becomes noticeable. Similarly, Jerome presents Hebrew as a conjoining of air and power. This air-power is relational, restructuring the obligations that one speaker owes to the other. It is also individuating, constituting the speaker in their permeability to air, and it opens up readings of scripture peculiar to the individual reader. In the linguistic world of late antiquity, this diversity would always be shameful, a return to the original site of Babel's transgression. Jerome shuts down that diversity and instead shows how the uox of Hebrew can be made to support the stable Christian economy of time, space and written words. The stabilisation of Hebrew uox in one particular Christocentric meaning does away with the language's airiness, its queer promise of other meanings. In Late Antiquity, reading strategies like the ones employed by Jerome effectively narrowed the abundant potential of meaning in scripture. This constraint of meaning paralleled a constraint of embodied practice. Once it was possible to imagine the Hebrew Bible in terms of homogeneous Christocentric meaning, it also became possible to imagine the space of Christian empire as a space of homogeneous humanity. ${ }^{89}$ The emasculating shame of human diversity could thereby be repressed. Extracting the air from Hebrew was a first step in making the politics of Christian empire a reality.

\footnotetext{
${ }^{89}$ Kathleen Biddick, The Typological Imaginary: Circumcision, Technology, History (Philadelphia: University of Pennsylvania Press, 2003).
} 